\title{
Üniversite Öğrencilerinin Öğretim Kalitesi Algısı Üzerine Bir Araştırma
}

\author{
Abdullah Karakaya a, İlknur K1lıç ${ }^{b^{*}}$, Mehmet Uçar ${ }^{c}$ \\ ${ }^{a}$ Karabük Üniversitesi, İktisadi ve İdari Bilimler Fakültesi, Karabük. \\ ${ }^{b}$ Çankırı Karatekin Üniversitesi, Meslek Yüksekokulu, Çankırı \\ cKarabük Üniversitesi, Sosyal Bilimler Enstitüsü, Karabük.
}

\begin{abstract}
$\ddot{O} z$
Üniversite öğrencilerinin öğretim kalitesi algıların belirlemeyi amaçlayan bu çalışma Çankırı Karatekin Üniversitesi Meslek Yüksekokulunda gerçekleştirilmiştir. Öğrencilerin öğretim kalitesi algısı Misyon, Öğretim Koşulları, Programları ve Öğretim Elemanları boyutlarında incelenmiştir. Araştırma kapsamında anket yöntemi ile elde edilen veriler, T testi, Anova, Tukey ve Korelasyon test istatistikleri ile analiz edilmiştir. Sonuçlar, kız öğrencilerin erkek öğrencilere kıyasla öğretim programları ve öğretim elemanları değişkenlerini daha kaliteli buldukların göstermektedir. Ayrıca öğrencilerin ikamet durumlarına göre Misyon ve Öğretim Koşulları değişkenleri ortalamalar farklılık göstermekte, ailesi ile ikamet eden öğrenciler ile yurt ve öğrenci evinde ikamet eden öğrenciler arasinda farklılık bulunmaktadır.
\end{abstract}

Anahtar Kelimeler: Üniversite, Kalite, Kalite Algısı, Yükseköğretimde Kalite

\section{A Survey on University Students' Perceptions on Teaching Quality}

\section{Abstract}

This sudy which aims to determine the perceptions of students on the quality of teaching conducted at Vocational School of Çankır Karatekin University. The perceptions of students were examined in the context of mission, teaching conditions, course programmes, and teaching staff. The data obtained from the survey analyzed using $t$ test, Anova, Tukey and Correlation tests. Results show that female students believe that the quality of teaching conditions and teaching staff are high when compared to male students. Besides there is a difference between the perceptions of the students who live with his family and students who stay at dormitory or a student house on mission and teaching conditions.

Keywords: University, Quality, Quality perceptions, Quality at higher education.

\section{Gíriş}

İnsanoğlu yaratılışından beri bilgiyi, erdemi, iletişim kurmayı, düşünmeyi, araştırmayı, öğrenmeyi ve hayatın anlamını keşfetmeyi kendine amaç edinmiştir. Bu tür zor sorulara cevap bulmak için de zeki, akıllı, becerikli ve bilgili insanları bir araya getiren, sinerji ile bilgi üreten ve yayan kurumlara ihtiyaç duymuştur. Bu noktada üniversite dediğimiz yükseköğretim kurumları ortaya çıkmaya başlamıştır (www.oocities.org).

Yükseköğretim kurumları da tüm diğer örgütlerde olduğu gibi üretmek zorundadırlar. Ancak eğitimin doğası gereği verimlilik unsurlarını mal üreten örgütler kadar açıklıkta ortaya koymak her zaman mümkün olmamaktadır. Eğitimde kaliteyi hem tasarımda kalite, hem de süreçte kalite şeklinde incelemek mümkündür. Eğitim 
örgütlerinde, daha çok çıtıda (sonuçların değerlendirilmesi) ve tasarımda kaliteye (müfredat tasarımı) dikkat edilmiştir. Süreçteki kaliteyle pek fazla ilgilenilmemiştir. Çıktıda kalitenin vurgulanması, birçok sürecin atlanmasına ve kalitenin oluşmasına olumsuz etki edebilir ve her zaman yeterli değildir. Eğer süreç uygun bir şekilde tasarlanır ve çalıştırılırsa, sonuçta ortaya kalite çıkacaktır (Özdemir, 2001: 254).

Ülkemizde yükseköğretime olan yüksek talebin karşılanması için üniversite ve yükseköğretim kontenjan sayısı hızla artmıştır. Bu artış üniversiteler arasında rekabeti gündeme getirmiştir. Öğrencilerin üniversite öğretim kalitesi alg1sı bu anlamda önem kazanmaktadır. Öğrencilerinin üniversiteden çeşitli düzeylerde eğitsel (akademik), sosyal, kültürel, sportif vb. beklentileri vardır. Üniversiteler öğrencilerine gelecekte iş dünyasının isteklerine cevap verecek şekilde öğretim programlarını sunmalı, yaratıcı ve yenilikçi düşünme fırsatları ile desteklemeli, eğitim ve araştırma çalışmaları ile ülkedeki, dünyadaki ve teknolojideki gelişmeleri sürekli takip etmelidir.

\section{LITERATÜR}

Bu bölüm iki başlıkta incelenmiş olup ilk kısımda üniversite tanımı yapılmış, üniversitelerin önemi üzerinde durulmuş ve üniversitelerdeki öğretim faaliyetlerine değinilmiştir. İkinci kısımda ise kalite kavramı tanımlanmış, kalitenin önemi ve boyutları, algılanan kalite ve yükseköğretimde kalite kavramlarına değinilmiştir.

\section{1. Üniversite Kavramı, Önemi ve Üniversitelerde Öğretim Faaliyetleri}

TDK sözlüğünde üniversite; “bilimsel özerkliğe ve kamu tüzel kişiliğine sahip, yüksek düzeyde eğitim, öğretim, bilimsel araştırma ve yayın yapan fakülte, enstitü, yüksekokul vb. kuruluş ve birimlerden oluşan öğretim kurumu" olarak tanımlanmaktadır. Eğitim sisteminin en üst düzeyinde yüksek öğretim bulunur. Üniversiteler yüksek öğretim hizmeti veren eğitim kurumları olup fakülte, enstitü, yüksekokul, konservatuvar, meslek yüksekokulu, araştırma ve uygulama merkezi ve benzeri birimlerden oluşur (YÖK Teşkilatı Kanunu, 1983: Madde 3).

Günümüz bilgi toplumunda en önemli görevleri üstlenen kurumlardan birisi, belki de birincisi üniversitelerdir. Çünkü üniversiteler bilgi ekonomisinin hammaddesi olan bilginin üretiminden ve dağıtımından sorumlu temel kurumlardır (Tonta, 1999: 367). Bundan dolayı üniversiteler bilgi odaklı bir vizyona sahip, üst otoritenin bilgisini ve uygulamasını sorgulamaksızın benimseyen/benimseten bir anlayışın yerine, öğrenmeye ve yeni bilgi edinimine önem veren, sorun çözümlerinin ve uygulamalarının bir öncekinin aynısının olmadığı, her yeni uygulamanın bir öncekine göre yeni bilgileri de içererek farklılık gösterdiği, bilimsel veri ve bilgi dışı simge sahiplerinin (makam, nüfuz, maddi / fiziksel güç) emirlerine ve uygulamalarına itaat yerine, bilginin ve bilimsel verilerin gücüne itaatin ön plânda olduğu, bilginin ve öğrenmenin ödüllendirildiği, makam, statü sembollerinin bilgi ve bunu uygulama gücüne göre dağıtıldığı öğretim kurumları olmalıdır (Celep, 2007: 17-18; Parlar, 2012: 205).

Üniversitelerin beş ayırıcı özelliği bulunmaktadır. Bunlar şu şekilde ifade edilmektedir (Bingöl, 2012: 43): 
- Soyut, kavramlaştırılmış, kurumsal bilgilerin üretildiği ve aktarıldığı bir kurum olması,

- Bilgi üretimi ve aktarımı işinin, bu işi sürekli meslek edinmiş kişilerce gerçekleştirilmesi,

- Söz konusu kurumların kendi ihtiyacı olan gelecekteki üyelerini de eğiterek, bilimsel üretim ve aktarımı kişisel eylem olmaktan çıkarması ve bu işi sürekli bir kurumsal etkinlik haline getirmesi,

- Söz konusu kurumların bitirilmesinin toplum içindeki belli mesleklerin icrasında ve belli sorumlulukların yüklenilmesinde bir ön koşul haline gelmesi,

- Eğitimin belli bir amacı gerçekleştirmesi için yapılması dolayısıyla belli bir programin izlenmesidir.

Türkiyede üniversitelerin tarihine bakıldığında Cumhuriyet'in ilanının hemen ardından başlatılan eğitim seferberliği ile yükseköğretim kurumlarının Anadolu'ya yayılmasındaki ilk adımlar atılmaya başlanmış ve Ankara'da 1925'te Hukuk Mektebi, 1926'da Gazi Eğitim Enstitüsü, 1930'da ise Ziraat Enstitüsü kurulmuştur. 1933'te İstanbul Üniversitesi kurulmuştur. Yüksek Mühendis Mektebi'nin 1944'te reorganize edilmesi ile İstanbul Teknik Üniversitesi, 1946'da Ankara Üniversitesi, 1955-1957 Yılları arasında kurulan Ege Üniversitesi, Karadeniz Teknik Üniversitesi, Orta Doğu Teknik Üniversitesi ve Atatürk Üniversitesi ile yükseköğretimin Anadolu'ya yayılması hız kazanmıştır (YÖK, 2005: 21). Günümüzde yükseköğretime olan yüksek talebin karşılanması için üniversite ve yükseköğretim kontenjan sayısı hızla artış kazanmış, bu artış üniversiteler arasında rekabeti gündeme getirmiştir.

Üniversitelerde eğitim-öğretim faaliyetlerinin yürütülmesinde iki tür program uygulanmaktadır. Bunlar resmi ve örtük program olmak üzere literatürde geçmiştir. Üniversitelerde uygulanan programlar ile dersler ve bu derslerin içerikleri büyük ölçüde birbirine benzemesine rağmen, bazı üniversiteler toplumdaki yeri ve öğrencilerinin kaliteleri bakımından farklılaşmaktadır. Üniversitelerde sadece resmi program uygulansaydı,üniversitelerin kalitesi bakımından aralarında çok fazla fark bulunmazdı. Burada üniversiteler arasındaki farkın sebebi, üniversitenin standartları, öğrencilerin geldikleri sosyal sınıf ve akademik başarı düzeyleri,üniversitedeki sosyal ve akademik yaşam vb. kısacası örtük programdır (Yüksel, 2002: 364).Örtük program, okullarda uygulanan resmî programlarda belirtilen amaç ve etkinliklerin dişında öğrenme-öğretme sürecinde bilinçli ya da farkında olmadan yapılan uygulamalar ve bunların sonucunda öğrencilerin kazandıkları özelliklerdir. Örtük program, öğrencilerin günlük okul deneyimlerinden edindikleri sosyal ve toplumsal öğrenmeleri de içerir (Veznedaroğlu, 2007:2).

\subsection{Kalite Kavramı}

\subsubsection{Kalitenin Tanımı ve Önemi}

Kalite, üretim ilişkileri ile meydana çıkmış ve günümüze kadar gelen süreçte oldukça ilgi duyulan bir konu olmuştur. Kalite ile ilgili bilinen ilk kayıtların M.Ö. 2150 yılına kadar uzandığı ileri sürülmekte, kalitenin bir kavram olarak ortaya çıkması 19. Yüzyıla rastlanmaktadır (Karaca, 2008: 62). Kalite kavramı ile ilgili pek çok tanıma 
rastlanılmaktadır. Kalite, bir malın veya hizmetin yetkinlik düzeyi olarak tanımlanabilir. Yetkinlik düzeyi ise üretici veya tüketici açısından bir malda belirli özellik veya özelliklerin var olması ile belirlenir (Akdağ, 2005:160).Kalite, müşterinin ihtiyaçlarının hangi oranda karşılandığı ile ilgili olan, ürün ya da hizmeti ekonomik yoldan üreten, tüketici ihtiyaçlarına cevap veren bir süreç; uzun vadeli bir yatırım ve üründe kusursuzluk arayan sistemli bir yaklaşımdır (Meraler ve Adıgüzel, 2012: 125). Kalite subjektif bir kavramdır ve bireysel algılama sonuçlarıyla anlam kazanır. Bu algılama insandan insana değişkenlik gösterir (Karcıoğlu ve Biçer, 2013: 2). Kalite istenen özelliklerde uygunluktur. Bu ifade ile iki boyuttan oluşur. İstenen özellikler ve bu özelliklere uygunluk. Bir ürün ya da hizmetin istenen özelliklere sahip olması tasarım kalitesi ile ilgilidir. Uygunluk kalitesi ise, müşteriye sunulan ürünün belirlenmiş olan tasarıma ne kadar uyduğu ile ilgilidir (Kıngır, 2006: 22).

\subsubsection{Kalitenin Boyutları}

Bir hizmet veya ürünün kalitesinin her bir boyutu birbirinden bağımsızdır. Kalitenin bir boyutu yüksek düzeyde olabiliyorken, diğer bir boyutu düşük düzeyde hissedilebilir. $\mathrm{Bu}$ üründen ürüne ve hizmetten hizmete de değişiklik gösterebilmektedir (Sözer vd., 2002: 47). Garvin, kalitenin boyutları üzerine oldukça kapsamlı ve çeşitli çalışmalar gerçekleştirmiş, 1984 yılında tüketicinin algıladığı kalitenin sekiz boyutunu tanımlamıştır. Bu boyutlar aşağıdaki gibi ifade edilebilir (Garvin, 1998: 217;Bumin ve Erkutlu, 2002: 84; Sözer vd., 2002: 47; Eroğlu, 2003: 13-15):

Performans: Mal veya hizmetin genellikle ölçülebilin, temel iş görme özelliklerini açıklar. Örneğin, bir otomobil için hız, konfor; bir televizyon için renk, ses görüntü gibi özelllikleri, hizmet işletmelerinde ise servis hızı, bekleme zamanı gibi sayılabilir.

Özellikler: "Özellik" kelimesi, bir ürünün temel fonksiyonunu tamamlayan kavram olarak ifade edilebilir. Bunar ürünün temel özellikleri yanında, sahip olduğu ve kullanıcı açısından cazibesini artıracak yan özellikleridir. Örneğin, havayolu şirketinin uçuşlarda verdiği ücretsiz ikramlar, çamaşır makinesinin pamuklu ya da yünlü programı, bir bölüm programının bilgi yanında öğrencilere liderlik özellikleri de kazandırması örnek sayılabilir.

Güvenilirlik: Ürünün arızalana veya servis görene kadar beklenen performans düzeyinde geçirdiği süre eya ne kadar sıklıkla arızalandığı ürünün güvenilirliğiyle ilgilidir. Ürünün kullanım ömrü içinde performans özelliklerinin sürekliliği. Önceden saptanan süre içinde mamulün arıza yapmadan çalışması. Ölçülebilen bir özellik olan güvenilirlik, ortalama ilk bozulma zamanı, bozulma süreleri arasındaki dönem vb. olabilir.

Uygunluk: Mal ya da hizmetin önceden belirlenmiş olan standartlara uygunluğu ile ilgilidir. Uygunluk kalitenin teknik boyutu hakkında tüketici veya kullanıcıya fikir vermektedir. Aynı zamanda uygunluk, istatistiksel kalite kontrolde ürünle ilgili özelliklerin nominal değerinden sapma oranıdır. 
Dayanıklılı: Bir ürün veya hizmetin kullanım ömrünün uzunluğudur. Ürün veya hizmetin yararlı olabilme süresidir. Örneğin, bilgisayarın ömrü.

Hizmet Görme Yeteneği: Kalitenin altıncı boyutu hizmet görme yeteneği, yani hız, çabukluk, nezaket, yeterlilik, ehliyet ve tamir edebilme kolaylığı olarak ifade edilmektedir. Örneğin, öğrenciye hizmet veren birimlerin talebe ne denli hızlı ve olumlu yanıt verdiği, buzdolabının bozulma olasılığ 1 ile birlikte serviste kaldığı süre, servis personelinin ilgisi, servisin doğru çözüm bulabilme özelliği gibi.

Estetik: Estetik, tüketicilerin beş duyusuna hitap eden ürün özellikleridir. Başka bir deyişle, ürünün kullanıcının beklentilerine uygun estetik yapıyı sağlayabilmesidir. Renk, ambalaj, biçim gibi özellikler ürünün performansını doğrudan etkilememekle beraber, tüketici beğenilerine yönelik estetik özellikler olarak nitelendirilebilir.

Algılanan Kalite: Tüketiciler her zaman ürünün tüm özellikleri ile ilgili ayrıntılı bilgi sahibi değildirler ve böyle durumlarda dolaylı bir takım ölçütler karar vermelerinde önemli rol oynamaktadır. Reklam faaliyetlerinde yaratılan ürün imajı, marka imajı gibi faktörler ürün kalitesinin tüketici tarafından olumlu veya olumsuz algılanmasında oldukça önemlidir.

\subsubsection{Kalite Algis1}

Kaliteyi gerçek kalite ve algılanan kalite olarak iki grupta incelemek uygun olur. Bir ürün veya hizmetin sunulması için harcanan çaba ve maliyetlerin, ürün veya hizmetin spesifikasyonlarına ulaşması halinde elde edilen kalite düzeyine "gerçek kalite" adı verilir. "Algılanan kalite" ise, sübjektif bir kavram olup, müşterinin algıladığ1 kalitedir ve söz konusu ürün veya hizmetin müşterinin beklentilerini karşılama düzeyini ifade eder (Işığıçok, 2004: 5). Gerçek kalite, algılanan kalite olmadan bir etkiye sahip değildir. Ürün veya hizmet işletmenin belirlediği şartlara ne kadar uyarsa uysun müşteri açısından yetersiz ise düşük kaliteli bir algılama kaçınılmazdır (Haciefendioğlu ve Koç, 2009: 148).

Kalite Algısı kalitenin aslında göreli bir kavram olması ve kişinin deneyim ve beklentilerine göre değişmesidir. Aynı zamanda araştırmalarda kalitenin iki şekli olduğu ifade edilmektedir. Buna göre Objektif kalite; objektif kalitede, ürünün gerçek teknik üstünlüğünden ya da ürünün mükemmelliğinden söz edilmektedir. Objektif kalitede kullanılan bazı ölçüler, önceden belirlenebilen ideal standart ya da standart ölçülerin doğruluğunu kantllayabilmektedir. Algılanan kalite; müşterinin bir ürün veya hizmetin niteliği, standarda uygunluğu veya standartların da üstünde olması, işlevlerini gerektiği gibi en azından arzu edilen süre kadar yerine getirebilmesi hakkındaki genel değerlendirmesi olarak tanımlamaktadır. Müşterilerin beklentilerinin onlar açısından karşılanma düzeyidir. Bu düzey müşteriler arasında da farklı değerlendirilmektedir. Algılanan kalite, müşterilerin beklentileri ile uyumluluk gösteriyor ise, müşteri tatmininin sağlanmasında olumlu yönde etkide bulunmakta; ancak müşteri beklentileri ile uyumsuzluk söz konusu ise, algılanan kalite müşteri tatmini üzerinde olumsuz yönde bir etki yaratmaktadır (Zeithaml, 1998: 3-4; Başanbaş, 2013: 4; Karakaş, 2012: 6). Şimşek (2009: 147)'a göre algılanan ürün veya hizmet 
kalitesinin markaya olan güvene, ürünün algılanan değerine ve marka sadakatine doğrudan etkisi olmasının yanı sıra algılanan bu ürün veya hizmet kalitesi müşteri memnuniyetini de dolaylı olarak etkilemektedir.

\subsubsection{Yükseköğretimde Kalite}

Bilgi çağını yaşan toplumlarda bilim ve teknolojinin önemi ön plana geçmiştir ve toplumun rekabet gücü sahip olduğu bilgi potansiyeline ve insan gücü kalitesine bağlıdır. Kaliteli insan gücü yetiştirmek için eğitim örgütleri toplumsal değişmelere, bilim ve teknolojideki gelişmelere uygun olarak eğitimin kalitesini sürekli geliştirmek zorundadır (Okçu, 2008: 284). Küreselleşme ve bilgi toplumunun eğitime getirdiği gelişmeler bazı hususların dikkate alınmasını gerektirmektedir. Bu hususlar şu şekilde ifade edilebilir (Balay, 2004:67):

- Bilgiyi temel alan eğitim programları izlenecektir,

- Çocuklara daha fazla düşünme, tartışma ve araştırma ortamı hazırlanacak; böylece, serbest düşünen, tartışan, araştıran ve bulduklarını değerlendirebilen bir toplum yapısı oluşturulacaktır,

- Yetişkinler eğitim süreci dışında bırakılmayacak; eğitim ve teknolojiye uyumları konusunda sürekli eğitilmeleri gerekecektir,

- Dersler ansiklopedik bilgileri yüklemek yerine, konuları ve olayları derinliğine anlamayı ve eleştirel düşünmeyi esas alacaktır,

- Okullar, öğrencileri gelecek için gerekli bilgiyle yüklemek yerine, okulda verilen bilgilerin yaşam boyu yetmeyeceği görüşünden hareketle öğrenmeyi öğrenmeye geçilecektir,

- Eğitimde sadece sözel ve sayısal zekâyı geliştirmek yerine, görsel, kinestetik, ritmik ve benlik gelişimini de içine alan çok yönlü zihin gelişimi hedeflenecektir.

Kaliteli eğitim, öğretim kurumunun mevcut imkânlarını en iyi şekilde kullanarak bilgi çağının gereklerine uygun biçimde, öğrenciye bilgiye ulaşmayı, bilgi üretmeyi öğreten, diğer ulusların bireyleri ile rekabet edebilecek yeteneğe sahip ve sürekli kendini yenileyen bireyler olarak yetişmelerini sağlayan,muhakeme eden, eleştiren, takım halinde çalışmayı ve yaratıcı düşünmeyi özendiren eğitimdir. Eğitim sisteminin kalitesi; insan kaynaklarının, fiziksel kaynakların, öğrenci hizmetlerinin, sosyal ve kültürel çevrenin, eğitim teknolojisinin, öğrenci-okul-sektör işbirliğinin, eğitim yönetiminin ve eğitim programının kalite-zenginlik dengesi ile yükseltilebilir (Okçu, 2008:285).

Eğitim sektöründe "Kaliteli ürün" kavram1, "kaliteli insan" olarak anlaşılmaktadır. Üniversitelerden çıktıları alarak ona girdiler sağlayan çevresel sistemler veya genel anlamda toplum, eğitim kurumlarının sürekli yenilenmesini gerektirmektedir. Bu yenilenmeye duyulan gereksinim her geçen gün önemini artırmaktadır.Bu çerçevede yükseköğretim kurumları, toplum ve iş sektörü ile bağlantılarını yeniden gözden geçirmek zorunda kalmıştır (Kalaycı, 2008: 166), bu bağlamda da yükseköğretimdeki kalite olgusu, ülke ekonomisine nitelikli bireyler sunma noktasında en önemli konu haline gelmektedir (Karahan, 2014: 24). 
Yüksek öğretimde kalite boyutu 20. yüzyılın ikinci yarısından itibaren giderek gelişmektedir. Bu gelişmeyi ortaya çıaran faktörlerin en önemlileri yüksek öğretim kurumlarının ve öğrencilerin sayısındaki artış ile yüksek öğretim kapsamının genişlemesi olarak belirtilebilir. Yükseköğretim kapsamı küresel ekonomi ve teknolojinin hızla gelişmesi ile yeni bir boyut kazanmaktadır. Daha önceleri yükseköğretimin en önemli öğesi olan bilgi toplumun büyük bir kısmı tarafından hızlı ve masrafsız olarak erişilebilir hale gelmiştir. Kitleleşme, uluslararasılaşma ve pazar etkisi yüksek öğretim sektörü içinde değişikliklerietkileyen en güçlü faktörlerdir (Palıulıs ve Labanauskıs, 2015: 141).

Yükseköğretimde kalite güvencesini sağlamak için bilinen iki yaklaşım bulunmaktadır. Bunlar; akreditasyon ve değerlendirme sistemidir (Kalayc1, 2008: 176). Yükseköğretim kalite güvencesi yönetmeliğinde akreditasyon, bir diş değerlendirici kurum tarafından belirli bir alanda önceden belirlenmiş akademik ve alana özgü standartların bir yükseköğretim kurumu veya programı tarafından karşılanıp karşılanmadığını ölçen değerlendirme ve dış kalite güvence süreci olarak tanımlanmaktadır. Akreditasyon, hem yüksek öğretim kurumunun kendi kendini dönemsel olarak değerlendirmesine (kurumsal özdeğerlendirme) hem de yüksek öğretim kurumunun kurum-dışı bağımsız akreditasyon ajansları tarafından dönemsel değerlendirilmesine imkan veren bir gönüllü kalite güvence sürecidir. Bir başka ifadeyle, yüksek öğretimde akreditasyon, akademik kalitenin iyileştirilmesi, saydamlık ve hesap verme sorumluluğunun aracıdır (Aktan, 2007: 1).

Değerlendirme sistemleri,öğrenci başarıları, mezun sayısı, istihdam edilen mezun sayısı, mezunların istihdam yerleri gibi sistemin öğrenme çıtıları ile ilgilidir (Kalaycı, 2008: 176). Öğrenme çıtılarının öğrenci ve iş piyasası temsilcilerinden alınacak geri besleme ile belirlenmesi ve buna dayalı olarak müfredatların yeniden oluşturulması ve belirli aralıklarla güncellemelerin yapılması yükseköğretimin eğitim kalitesini olumlu etkileyecektir. Bu kaliteden hem öğrenciler, hem de iş piyasası olumluetkilenecektir. Bu kalitenin sağlanması için öğrencilerin nasıl öğrendiğine ve etkin öğrenme ortamlarının tasarlanmasına odaklanmak gerekmekte, öğrenme çıtılarına dayalı olarak uygun öğretim stratejilerinin belirlenmesi ve buna paraleleğerlendirme tekniklerinin değiştirilmesi gerekmektedir(Özer, Gür, ve Küçükcan, 2010: 41-42).

Yükseköğretimde öğretim kalitesi kapsamında en fazla etkili olan unsurun öğretim elemanları olduğu konusunda araştırıcılar arasında görüş birliği vardır. Öğretim elemanlarının mesleki yeterlilikleri, kendi branşlarındaki yeniliklere karşı ilgili olmaları, mesleki deneyimleri ve kişisel olarak olumlu özelliklere sahip olmaları daha kaliteli hizmet sunmalarında çok etkili olmaktadır. Yöneticiler de gerekli öğretim araç ve gereçlerini temin ederek, öğretim sürecini denetim altında tutarak sunulan öğretim hizmetinin kalitesini yükseltme imkânına sahiptirler. Öğretim kalitesinin artırılmasında etkili olan bir diğer unsurda araç ve gereçlerdir. Hizmetin sunumunda kullanılan araçların çağın teknolojisine uygun olması ve tüm öğrencilerin bu araçlardan eşit şekilde yararlandırılması gerekir. Diğer taraftan içinde eğitim yapılan 
binanın temizlik, 1S1, ses yalıtımı, konfor, tertip ve düzen gibi fiziksel koşulları da sunulan hizmetin kalitesini etkilemektedir (Taşkın ve Büyük, 2002: 210).

\section{ARAŞTIRMA}

Araştırmanın amacı üniversite öğrencilerinin, öğretim kalitesi algılarını belirlemektir. Üniversitelerin ve öğrenci kontenjanlarının hızla arttığı günümüzde öğrencilerin üniversite kalite algısı oldukça önem kazanmaktadır. Bu durum çalışmanın önemini ortaya koymaktadır. Ulaşılmak istenen amaca yönelik öngörülen hipotezler aşağıdaki sıralanabilir:

Hı: Öğretim kalitesi algısı öğrencilerin cinsiyetlerine göre farklılık göstermektedir.

$\mathbf{H}_{2}$ : Öğretim kalitesi algısı öğrencilerin öğrenim gördükleri sınıflarına göre farklılık göstermektedir.

$\mathbf{H}_{3}$ : Öğretim kalitesi algısı öğrencilerin yaşlarına göre farklılık göstermektedir.

$\mathbf{H}_{4}$ :Öğretim kalitesi algısı öğrencilerin ikamet durumlarına göre farklılık göstermektedir.

H5: Öğretim kalitesi algısını belirleyen boyutlar arasında ilişki vardır.

Araştırmada veriler, öğrencilerin hali hazırda var olan durumlarının ne olduğunu betimleyip açıklayan anketlerle yani Betimsel Araştırma yöntemi (Sönmez ve Alacapınar, 2011: 40-46) ile toplanmıştır. Araştırmada tanımlayıcı bilgilere ilişkin Yaş, Cinsiyet, Sınıf ve İkamet Durumuna yönelik 4 adet soru, "Üniversite Öğretim Kalitesi Alg1sı" ölçmeye yönelik fonksiyonel değişkenlere ilişkin ise 5'li likert ölçeğine (1= Hiç Katılmıyorum, 5= Tamamen Katıliyorum) göre oluşturulmuş 23 adet soru bulunmaktadır. Kullanılan ölçeğin iç tutarlılığı, Cronbach Alfa katsayısıyla hesaplanmıştır. Ölçeğin geneline ilişkin güvenilirlik katsayısı $\alpha=0,925$ olarak belirlenmiş olup, araştırma için kullanılan ölçeğin yüksek derecede güvenilir olduğunu söylemek mümkündür.

Fonksiyonel değişkenleri ölçen maddeler aşağıdaki gibi gruplandırılmıştır:

Misyon 1. Yüksekokulumuz misyonuna yönelik program ve uygulamaları gerçekleştirmektedir.

2. Yüksekokulumuz vizyonuna yönelik program ve uygulamaları amaç edinmektedir.

3. Yüksekokulumuz iyi bir imaja sahiptir.

4. Yüksekokulumuzun eğitim-öğretime yönelik hedefleri vardır.

5. Yüksekokulumuzun eğitim-öğretim hedeflerinin farkındayım.

Öğretim $\quad$ 6. Kütüphane kaynakları ve veri tabanları bilgiye kolay ulaşma Koşulları firsatı sağlamaktadır.

7. Yüksekokulda internete kolay ve hızlı erişilebilmekteyim.

8. Öğretme-öğrenme ortamını etkileyen fiziki şartlar uygundur.

9. Sınıfların doluluk oranları öğretime uygundur.

10. Dersleri etkili bir şekilde takip edilebilmekteyim. 
Öğretim Programları

Öğretim Elemanları
11. Yüksekokulumuzun öğretim programları iş hayatının gerekliliklerini karşılamaktadır.

12. Öğretim programları hayat boyu öğrenme bilincini içermektedir.

13. Öğretim programları bireysel öğrenmeyi teşvik eder.

14. Öğretim programları öğrencilerin problem çözme becerisini geliştirmeye yönelik düzenlenmiştir.

15. Öğretim programları kendini ifade etme becerisi kazandırmaktadır.

16. Dersler içerik açısından birbirini tamamlamaktadır.

17. Öğrenciler danışmanlarına kolayca ulaşabilmektedir.

18. Öğretim elemanları ile etkili iletişim kurulmaktadır.

19. Öğretim elemanları ders içeriklerini güncel gelişmeler ile desteklemektedir.

20. Öğretim elemanları öğrencilere bireysel öğrenme olanakları sunmaktadır.

21. Öğretim elemanları öğretim sürecinde güncel öğretim yöntemlerini kullanmaktadır.

22. Öğretim elemanları öğrencilerin başarılı olmalarına odaklıdır.

23. Öğretim elemanları araştırmalarını öğretime dahil etmektedirler.

Araştırmanın evrenini Çankırı Karatekin Üniversitesi Meslek Yüksekokulu Sosyal Programlar öğrencileri oluşturmaktadır. Devam eden yaklaşık 1300 öğrencinin olduğu bilinmektedir (Meslek Yüksekokul Müdürlüğü, 2015).\%95 güven aralı̆̆ında örneklem büyüklüğünün 297 olduğu tespit edilmiş olup araş九ırmaya 306 anket dâhil edilmiştir. Araştırma verileri istatistiksel analiz paket programı ile analiz edilmiştir. Verilerin analizi ile ilgili olarak; $\mathrm{T}$ testi, Anova, Tukey testi ve Korelasyon analizi kullanılmıştır. Araştırma verilerinin Kolmogorov-Simirnov testi sonucunda basıklık ve çarpıklık değerlerine ve Levene istatistiği sonuçlarına bakılarak parametrik testlere uygun olduğu görülmüştür.

\section{BULGULAR}

Araştırma bulguları tanımlayıcı bilgilere ilişkin bulgular ve fonksiyonel değişkenlere yönelik bulgular olarak iki kısımda verilmekte olup, sonuçlar tablolarla sunularak, yorumlanmıştır.

\subsection{Tanımlayıcı Bilgilere İlişkin Bulgular}

Araştırmaya katılan öğrencilerin Yaş, Cinsiyet, Sınıf ve İkamet durumlarını açiklayan bulgular Tablo 1'de sunulmuştur. 
Tablo 1. Tanımlayıcı Bilgilere Yönelik İstatistikler

\begin{tabular}{|l|l|c|c|}
\hline \multicolumn{2}{|c|}{ DEĞIŞKENLER } & N & \% \\
\hline \multirow{4}{*}{ Yaş } & $18-20$ & 171 & 56 \\
\cline { 2 - 4 } & $21-23$ & 107 & 35 \\
\cline { 2 - 4 } & $24-\ldots .$. & 28 & 9 \\
\hline \multirow{2}{*}{ Cinsiyet } & Kadın & 155 & 51 \\
\cline { 2 - 4 } & Erkek & 151 & 49 \\
\hline \multirow{2}{*}{ Sınıfı } & 1. Sınıf & 138 & 45 \\
\cline { 2 - 4 } & 2. Sinıf & 168 & 55 \\
\hline \multirow{2}{*}{$\begin{array}{l}\text { İkamet } \\
\text { Durumu }\end{array}$} & Yurt & 109 & 36 \\
\cline { 2 - 4 } & Öğrenci Evi & 116 & 38 \\
\cline { 2 - 4 } & Aile & 81 & 26 \\
\hline \multicolumn{2}{|c|}{ Toplam } & 306 & 100 \\
\hline
\end{tabular}

Tablo 1'e göre öğrencilerin \%56 ile büyük çoğunluğu 18-20 yaş aralığında olup, sadece \%9'u 24 yaş ve üstüdür. Böylece oldukça genç bir popülasyonun bulunduğu gözlenmiştir. Araştırmaya katılan öğrencilerin \%51'ini Kadın iken, araştırma dahilindeki öğrencilerin \%55 ile büyük çoğunluğu ise 2. Sınıfta öğrenimlerine devam etmektedir. Araştırmaya katılan öğrencilerin \%38 ile çoğunluğu öğrenci evinde ikamet ederken, yurtta ikamet eden öğrencilerin oranı \%36'dır. Ailesi ile ikamet eden öğrencilerin oranı ise \%26'dır.Araştırmaya katılan öğrencilerin $\% 74^{\prime}$ ünün ailesinden ayrı yaşayarak öğrenimlerine devam ettikleri görülmektedir.

\subsection{Fonksiyonel Değişkenlere Yönelik Bulgular}

Öğrencilerin öğretim kalitesi algısına yönelik puan ortalamalarının cinsiyete göre farklılık gösterip göstermediğinin belirlenmesi için $\mathrm{T}$ testi sonuçları Tablo 2'de sunulmuştur.

Tablo 2. Cinsiyete Göre Kalite Algısı İstatistikleri

\begin{tabular}{|c|c|c|c|c|c|c|c|}
\hline \multicolumn{2}{|c|}{ Cinsiyet } & $\mathbf{N}$ & $\bar{x}$ & $S$ & Sd & $\mathbf{t}$ & $\mathbf{p}$ \\
\hline \multirow{2}{*}{ Misyon } & Kadın & 155 & 3,672 & 0,921 & \multirow{2}{*}{304} & \multirow{2}{*}{1,695} & \multirow{2}{*}{$0,091^{*}$} \\
\hline & Erkek & 151 & 3,494 & 0,917 & & & \\
\hline \multirow{2}{*}{$\begin{array}{l}\text { Öğretim } \\
\text { Koşulları }\end{array}$} & Kadın & 155 & 3,503 & 0,797 & \multirow{2}{*}{304} & \multirow{2}{*}{0,577} & \multirow{2}{*}{0,564} \\
\hline & Erkek & 151 & 3,449 & 0,845 & & & \\
\hline \multirow{2}{*}{$\begin{array}{l}\text { Öğretim } \\
\text { Programları }\end{array}$} & Kadın & 155 & 3,845 & 0,770 & \multirow{2}{*}{304} & \multirow{2}{*}{3,392} & \multirow{2}{*}{$0,001^{*}$} \\
\hline & Erkek & 151 & 3,530 & 0,849 & & & \\
\hline \multirow{2}{*}{$\begin{array}{l}\text { Öğretim } \\
\text { Elemanları }\end{array}$} & Kadın & 155 & 3,977 & 0,806 & \multirow{2}{*}{304} & \multirow{2}{*}{2,079} & \multirow{2}{*}{$0,038^{*}$} \\
\hline & Erkek & 151 & 3,784 & 0,814 & & & \\
\hline
\end{tabular}

$$
\mathrm{P}<0,05^{*}
$$

Tablo 2'den görüldüğü üzere öğrencilerin öğretim kalitesi alg1sına yönelik puan ortalamalarının cinsiyete göre farklılık gösterip göstermediğinin belirlenmesi için yapılan $\mathrm{T}$ testi sonuçlarına göre; misyon ve öğretim koşulları başlı̆̆ı ile açıklanan değişkenlerin ortalamalarının cinsiyete göre farklılık göstermediği ( $>>0,05)$, öğretim programları ve öğretim elemanları değişkenlerinin ortalamalarının ise cinsiyete göre 
farklılaştı̆̆ gözlenmiştir $(\mathrm{p}<0,01)$, ( $\mathrm{p}<0,05)$. Ulaşılan bu sonuç ile “ $\mathrm{H}_{1}$ : Öğretim kalitesi alg1sı öğrencilerin cinsiyetlerine göre farklılık göstermektedir." hipotezi öğretim programları ve öğretim elemanları boyutları için kabul edilirken, misyon ve öğretim koşulları boyutları için reddedilmiştir.

Öğretim kalitesi algısının öğrencilerin öğrenim gördüklerini sınıf değişkenine göre farklılık gösterip göstermediğinin belirlenmesine yönelik $\mathrm{T}$ testi Tablo $3^{\prime}$ te verilmiştir.

Tablo 3. Öğrenim Sınıfına Göre Kalite Algısı İstatistikleri

\begin{tabular}{|c|c|c|c|c|c|c|c|}
\hline \multicolumn{2}{|c|}{ Sinif } & $\mathbf{N}$ & $\bar{x}$ & $S$ & $S d$ & $t$ & $p$ \\
\hline \multirow{2}{*}{ Misyon } & 1. Sinif & 138 & 3,501 & 0,919 & \multirow{2}{*}{304} & \multirow{2}{*}{1,427} & \multirow{2}{*}{0,155} \\
\hline & 2. Sinif & 168 & 3,652 & 0,921 & & & \\
\hline \multirow{2}{*}{$\begin{array}{l}\text { Öğretim } \\
\text { Koşulları }\end{array}$} & 1. Sinif & 138 & 3,462 & 0,852 & \multirow{2}{*}{304} & \multirow{2}{*}{0,273} & \multirow{2}{*}{0,785} \\
\hline & 2. Sinif & 168 & 3,488 & 0,795 & & & \\
\hline \multirow{2}{*}{$\begin{array}{l}\text { Öğretim } \\
\text { Programları }\end{array}$} & 1. Sinif & 138 & 3,693 & 0,839 & \multirow{2}{*}{304} & \multirow{2}{*}{0,061} & \multirow{2}{*}{0,952} \\
\hline & 2. Sinif & 168 & 3,687 & 0,813 & & & \\
\hline \multirow{2}{*}{$\begin{array}{l}\text { Öğretim } \\
\text { Elemanları }\end{array}$} & 1. Sinif & 138 & 3,827 & 0,840 & \multirow{2}{*}{304} & \multirow{2}{*}{1,066} & \multirow{2}{*}{0,287} \\
\hline & 2. Sinif & 168 & 3,926 & 0,792 & & & \\
\hline
\end{tabular}

$\mathrm{P}<0,05^{*}$

Tablo 3’te görüldüğü üzere öğrencilerin öğretim kalitesi algısına yönelik puan ortalamalarının öğrenim sınıflarına göre farklılık gösterip göstermediğinin belirlenmesi için yapılan $\mathrm{T}$ testi sonuçlarına bakıldığında herhangi bir farklılığın bulunmadığı gözlenmektedir $(\mathrm{p}>0,05)$. “ $\mathrm{H}_{2}$ : Öğretim kalitesi algısı öğrencilerin öğrenim gördükleri sınıflarına göre farklılık göstermektedir." hipotezi reddedilmiştir.

Öğretim kalitesi algısının öğrencilerin yaşlarına göre farklılık gösterip göstermediğinin belirlenmesine yönelik ANOVA testi Tablo 4'te verilmiştir.

Tablo 4. Yaşa Göre Kalite Algısı İstatistikleri

\begin{tabular}{|c|c|c|c|c|c|c|}
\hline & $\begin{array}{c}\text { Varyansın } \\
\text { Kaynağı }\end{array}$ & $\begin{array}{c}\text { Kareler } \\
\text { Toplamı }\end{array}$ & Sd & $\begin{array}{c}\text { Kareler } \\
\text { Ort. }\end{array}$ & $\mathbf{F}$ & $\mathbf{p}$ \\
\hline \multirow{3}{*}{ Misyon } & Gruplar arası & 0,725 & 2 & 0,362 & \multirow{3}{*}{0,425} & \multirow{3}{*}{0,654} \\
\hline & Gruplar içi & 258,640 & 303 & 0,854 & & \\
\hline & Toplam & 259,365 & 305 & & & \\
\hline \multirow{3}{*}{$\begin{array}{l}\text { Öğretim } \\
\text { Koşulları }\end{array}$} & Gruplar arası & 2,316 & 2 & 1,158 & \multirow{3}{*}{1,727} & \multirow{3}{*}{0,180} \\
\hline & Gruplar içi & 203,135 & 303 & 0,670 & & \\
\hline & Toplam & 205,451 & 305 & & & \\
\hline \multirow{3}{*}{$\begin{array}{l}\text { Öğretim } \\
\text { Programları }\end{array}$} & Gruplar aras1 & 0,123 & 2 & 0,061 & \multirow{3}{*}{0,090} & \multirow{3}{*}{0,914} \\
\hline & Gruplar içi & 206,959 & 303 & 0,683 & & \\
\hline & Toplam & 207,082 & 305 & & & \\
\hline \multirow{3}{*}{$\begin{array}{l}\text { Öğretim } \\
\text { Elemanları }\end{array}$} & Gruplar aras1 & 0,428 & 2 & 0,214 & \multirow{3}{*}{0,321} & \multirow{3}{*}{0,726} \\
\hline & Gruplar içi & 202,058 & 303 & 0,667 & & \\
\hline & Toplam & 202,486 & 305 & & & \\
\hline
\end{tabular}

$\mathrm{P}<0,05^{*}$ 
Öğrencilerin üniversite öğretim kalitesi algısının yaş değişkenine göre farklılık gösterip göstermediğinin belirlenmesi için ilişkisiz üç ya da daha çok örneklem ortalaması arasındaki farkın anlamlılığını test etmek amacıyla Anova (Büyüköztürk, 2008:49) testi uygulanmış olup Tablo 4'te görüldüğü üzere anlamlı bir farklılığa rastlanılmamıştır $(\mathrm{p}>0,05)$. “H3: Öğretim kalitesi algısı öğrencilerin yaşlarına göre farklılık göstermektedir." hipotezi reddedilmiştir.

Öğretim kalitesi algısının öğrencilerin ikamet ettikleri yere göre farklılık gösterip göstermediğinin belirlenmesine yönelik ANOVA testi Tablo 5'de verilmiştir.

Tablo 5. İkamet Durumuna Göre Kalite Algısı İstatistikleri

\begin{tabular}{|c|c|c|c|c|c|c|}
\hline & $\begin{array}{c}\text { Varyansın } \\
\text { Kaynağ1 }\end{array}$ & $\begin{array}{c}\text { Kareler } \\
\text { Toplamı }\end{array}$ & Sd & $\begin{array}{c}\text { Kareler } \\
\text { Ort. }\end{array}$ & $\mathbf{F}$ & $\mathbf{p}$ \\
\hline \multirow{3}{*}{ Misyon } & Gruplar arası & 5,728 & 2 & 2,864 & \multirow{3}{*}{3,422} & \multirow{3}{*}{$0,034^{*}$} \\
\hline & Gruplar içi & 253,636 & 303 & 0,837 & & \\
\hline & Toplam & 259,365 & 305 & & & \\
\hline \multirow{3}{*}{$\begin{array}{l}\text { Öğretim } \\
\text { Koşulları }\end{array}$} & Gruplar arası & 5,026 & 2 & 2,513 & \multirow{3}{*}{3,799} & \multirow{3}{*}{$0,023^{*}$} \\
\hline & Gruplar içi & 200,425 & 303 & 0,661 & & \\
\hline & Toplam & 205,451 & 305 & & & \\
\hline \multirow{3}{*}{$\begin{array}{l}\text { Öğretim } \\
\text { Programlar1 }\end{array}$} & Gruplar arası & 0,635 & 2 & 0,318 & \multirow{3}{*}{0,466} & \multirow{3}{*}{0,628} \\
\hline & Gruplar içi & 206,447 & 303 & 0,681 & & \\
\hline & Toplam & 207,082 & 305 & & & \\
\hline \multirow{3}{*}{$\begin{array}{l}\text { Öğretim } \\
\text { Elemanları }\end{array}$} & Gruplar arası & 2,353 & 2 & 1,176 & \multirow{3}{*}{1,781} & \multirow{3}{*}{0,170} \\
\hline & Gruplar içi & 200,133 & 303 & 0,661 & & \\
\hline & Toplam & 202,486 & 305 & & & \\
\hline
\end{tabular}

$\mathrm{P}<0,05^{*}$

Tablo 5'te sonuçları verilen, öğrencilerin üniversite öğretim kalitesi algısının İkamet durumuna göre farklılık gösterip göstermediğinin belirlenmesi için yapılan Anova testi, misyon ve öğretim koşulları boyutları ile öğrencilerin ikamet durumları arasındaki anlamlı farklılığı işaret etmektedir. $(\mathrm{p}<0,05)$. Farkların hangi gruplar arasında olduğunu belirlemek amacıyla Tukey testi yapılmış olup, her iki değişken için farkın kaynağı Aile -Yurt, Aile - Öğrenci Evi olarak açıklanmıştır. Buna göre ailesiyle ikamet eden öğrencilerin yurtta ve öğrenci evinde ikamet eden öğrencilere göre meslek yüksekokulu misyon ve öğretim koşullarına yönelik kalite algılarını ölçen ifadeleri daha yüksek puanladıkları sonucuna ulaşılmaktadır. Öğretim programları ve öğretim elemanları boyutlarıyla ikamet durumu arasında ise farklılık belirlenmemiştir ( $p>0,05) .{ }^{\prime \prime} \mathrm{H}_{4}$ : Öğretim kalitesi alg1sı öğrencilerin ikamet durumlarına göre farklılık göstermektedir." hipotezi misyon ve öğretim koşulları boyutları için kabul edilirken, öğretim programları ve öğretim elemanları boyutları için reddedilmiştir.

Tablo 6' da fonksiyonel değişkenlerin kendi aralarındaki ilişkinin ölçülmesine yönelik Korelasyon Analizi sonuçları verilmektedir. 
Tablo 6. Fonksiyonel Değişkenler Arasındaki İlişkinin Belirlenmesine Yönelik İstatistikler

\begin{tabular}{|c|c|c|c|c|c|}
\hline & & Misyon & $\begin{array}{l}\text { Öğretim } \\
\text { Koşulları }\end{array}$ & $\begin{array}{l}\text { Öğretim } \\
\text { Prog. }\end{array}$ & $\begin{array}{l}\text { Öğretim } \\
\text { El. }\end{array}$ \\
\hline \multirow{3}{*}{ Misyon } & Kor. & 1 & & & \\
\hline & $\mathrm{P}$ & & & & \\
\hline & $\mathrm{N}$ & 306 & & & \\
\hline \multirow{3}{*}{$\begin{array}{l}\text { Öğretim } \\
\text { Koşulları }\end{array}$} & Kor. & $0,541^{* *}$ & 1 & & \\
\hline & $\mathrm{P}$ & 0,000 & & & \\
\hline & $\mathrm{N}$ & 306 & 306 & & \\
\hline \multirow{3}{*}{$\begin{array}{l}\text { Öğretim } \\
\text { Programları }\end{array}$} & Kor. & $0,612^{* *}$ & $0,682^{* *}$ & 1 & \\
\hline & $\mathrm{P}$ & 0,000 & 0,000 & & \\
\hline & $\mathrm{N}$ & 306 & 306 & 306 & \\
\hline \multirow{3}{*}{$\begin{array}{l}\text { Öğretim } \\
\text { Elemanları }\end{array}$} & Kor. & $0,570^{* *}$ & $0,541^{* *}$ & $0,675^{* *}$ & 1 \\
\hline & $\mathrm{P}$ & 0,000 & 0,000 & 0,000 & \\
\hline & $\mathrm{N}$ & 306 & 306 & 306 & 306 \\
\hline
\end{tabular}

$\mathrm{P}<0,05^{*}$

Tablo 6'da sonuçları görüldüğü üzere, öğrencilerin kalite algısını etkileyen boyutlar arasındaki ilişkiyi ölçmek amacıyla en az iki değişken arasında anlamlı bir ilişkinin olup olmadığını yoklamada kullanılan korelasyon analizi uygulanmıştır. Korelasyon +1 ile -1 arasında değer alabilir. +1 'e yaklaştıkça olumlu yönde yüksek bir korelasyondan, sıfıra yaklaştıkça ilişkinin yokluğundan, -1'e yaklaştıkça ters bir ilişkiden söz edilebilir (Sönmez ve Alacapınar, 2011: 140). Tablo 6'ya bakıldığında öğrencilerin öğretim kalitesi algısını belirleyen boyutların tümü arasında pozitif ve anlamlı bir ilişki olduğu görülmektedir. Bu boyutların herhangi birindeki değişiklik diğerinde de aynı etkiyi gösterecektir.

\section{SONUÇ}

Müşteri, herhangi bir kişi veya kurumun faaliyetleri sonuçlarından faydalanan kişi veya gruplar olarak ifade edilebilir. Müşterilerin gereksinimlerini karşılama derecesi olarak tanımlanabilen kalite, tüm süreçlerin etkin yönetimi ve sürekli iyileştirilmesini kapsamaktadır. Yükseköğretim kurumlarının ana amaçlarından biri olan eğitim-öğretim hizmetlerinden yararlanan öğrencilerin öğretim kalitesi alg1sı yükseköğretim kurum ve kontenjanlarının gittikçe arttı̆̆ı günümüzde dikkate alınması gereken önemli hususlardan biridir. Yükseköğretim kurumlarının sürekli olarak gelişim içinde olmaları devamlılıklarını sağlamaları açısından önemli bir faktördür.

$\mathrm{Bu}$ araştırmada öğrencilerin öğretim kalitesi algısı misyon, öğretim koşulları, programlar ve öğretim elemanları alt boyutlarında incelenmiştir. Üniversite öğretim kalitesi algısını açılayan bu alt boyutları arasında yapılan Korelasyon Analizi sonucunda bu boyutların birbiriyle ilişkili olduğu sonucuna varılmıştır. Misyon boyutunu açıklayan toplam varyansın yaklaşı \%30'unun öğretim koşulları 
boyutundan, yaklaşık \%38'ininin öğretim programları boyutundan, yaklaşık \%32'sinin ise öğretim elemanları boyutundan kaynaklandığı söylenebilir.

Yapılan T testi ile kız öğrencilerin erkek öğrencilere göre öğretim programları ve öğretim elemanları boyutlarını daha yüksek puanladıkları ortaya çıkmıştır. Bu sonuçlara dayanılarak, erkek öğrencilerin öğretim programları ve öğretim elemanları boyutlarına ilişkin kalite algısını artırmaya yönelik (bireysel öğrenme, problem çözme, iş dünyasının gerektirdiği nitelikleri taşıma gibi) iyileştirmeler yapılması önerilebilir.

Öğrencilerin ikamet durumlarına göre misyon ve öğretim koşulları boyutlarının ortalamalarının farklılaştığı, yapılan Tukey testi ile bu farklılığın ailesi ile ikamet eden öğrenciler ile yurt ve öğrenci evinde ikamet eden öğrenciler arasında olduğu sonucuna varılmıştır. Ailesi ile ikamet eden öğrencilerin misyon ve öğretim koşulları boyutlarına ilişkin kalite algısının yurtta ve öğrenci evinde ikamet eden öğrencilere göre yüksek olduğu gözlenmektedir. Bu durum ailesinden ayrı yaşayan öğrencilerin yaşam memnuniyetlerinden kaynaklanabilir. Buna yönelik araştırmalar için bu sonuç 1şık olacaktır. Öğrenciler için getirilebilecek bir öneri de ailesinden ayrı ikamet ederek öğrenimlerini sürdüren öğrencilere ilişkin oryantasyonve kaynaşma programları düzenlenebileceğidir.

\section{KAYNAKÇA}

Akdağ, M. (2005). Toplam Kalite Yönetimi ve Örgüt İçindeki Yeri, Selçuk İletişim, 4(1): 159-170.

Aktan, C. C. ve Gencel, U. (2007). Yükseköğretimde Akreditasyon, İzmir Yaşar Üniversitesi Yayın, 25 Ekim 2015 tarihinde http://www.canaktan.org/egitim/akreditasyon/aktanakredit.pdf: adresinden erişildi.

Balay, R. (2004). Küreselleşme, Bilgi Toplumu ve Eğitim, Ankara Üniversitesi Eğitim Bilimleri Fakültesi Dergisi, 37(2): 61-82.

Başanbaş, Ş. (2013). Algılanan Kalite İle Müşteri Tatmini Arasındaki İlişki: Filtre Kullanıcıları Üzerine Yapılan Amprik Bir Çalışma, Akademik Bakış Dergisi, 34. 28 Ekim 2015 tarihinde http://www.acarindex.com/dosyalar/makale/acarindex-1423867874.pdf adresinden erişildi.

Bingöl, B. (2012). Üniversite Özerkliğinin Değişen Tanımı ve Üniversitelerin Yeniden Yapılandırılması, Hacettepe Hukuk Fakültesi Dergisi, 2(2): 39-75.

Bumin, B., \& Erkutlu, H. (2002). Topam Kalite Yönetimi ve Kıyaslama (Benchmarking) İlişkileri, Gazi Üniversitesi İktisadi ve İdari Bilimler Fakültesi Dergisi, (1): 83-100.

Büyüköztürk, Ş. (2008). Sosyal Bilimler için Veri Analizi El Kitabı İstatistik, Araştırma Deseni SPSS Uygulamalar ve Yorum, Ankara: Pegem Akademi Yayıncilık.

Celep, C. (2007). Okullarda bilgi yönetim kültürü geliştirmede okul yöneticilerinin rolü, Eğitime Bakış Dergisi, 8: 15-21.

Eroğlu, E. (2003). Toplam Kalite Yönetimi Uygulamalarının Yapısal Eşitlik Modeli İle Analizi, (YayınlanmamışDoktora Tezi) İstanbul Üniversitesi Sosyal Bilimler Enstitüsü İşletme Anabilim Dalı Sayısal Yöntemler Bilim Dalı, İstanbul.

Garvin, D. A. (1998). Managing Quality. New York: The Free Press. 
Hacıefendioğlu, Ş. ve Koç, Ü. (2009). Hizmet Kalitesi Algılamalarının Müşteri Bağlllığına Etkisi ve Fast-Food Sektöründe Bir Araştırma, Kocaeli Üniversitesi Sosyal Bilimler Enstitüsü Dergisi, 2(18): 146-167.

http://www.oocities.org/vsametoglu24/VahitSametoglu_Yazi-066.pdf. 30 Ekim 2015 tarihinde alınd1.

Işığıçok, E. (2004). Toplam Kalite Yönetimi Bakış Açısıyla İstatistiksel Kalite Kontrol. Bursa : Ezgi Kitabevi.

Kalayc1, N. (2008). Yükseköğretimde Uygulanan Toplam Kalite Yönetimi Sürecinde Gözardı Edilen Unsurlardan TKY Merkezi ve Eğitim Programları, Türk Eğitim Bilimleri Dergisi, 6(2): 163-188.

Karaca, E. (2008). Eğitimde Kalite Arayışları ve Eğitim Fakültelerinin Yeniden Yapılandırılması, Dumlupınar Üniversitesi Sosyal Bilimler Dergisi, (21): 61-80.

Karahan, M. (2014). Yükseköğretimde Kalite Yönetim Sistemi Toplam Kalite Yönetimi Bağlamında Değerlendirilmesi: Selçuk Üniversitesi Hadim ve Sarayönü Meslek Yüksekokulları Örneği, Atatürk Üniversitesi İktisadi ve İdari Bilimler Dergisi, 28(3): 23-41.

Karakaş, S. (2012). Cep Telefonu Pazarında Müşteri Sadakatinin Yapısal Eşitlik Modellemesi İle İncelenmesi, İstanbul Üniversitesi Sosyal Bilimler Dergisi, 1-23.

Karcıoğlu, R., \& Biçer, E. (2013). Toplam Kalite Yönetiminin İşletme Maliyetleri Üzerine Etkisi: Kalite Belgesi Öncesi ve Sonrası Dönem Karşılaştırması, Muhasebe ve Denetime Bakış, 125.

Kıngır, S. (2006). Toplam Kalite Yönetimi.Ankara: Nobel Yayın Dağıtım.

Meraler, S., ve Adıgüzel, A. (2012). Eğitim Fakültesi Öğrencilerinin Yükseköğretimdeki Kaliteye İlişkin Görüşlerinin Belirlenmesi, Adıyaman Üniversitesi Sosyal Bilimler Enstitüsü Dergisi, (9): 123-144.

Okçu, V. (2008). Eğitimde Toplam Kalite Yönetiminin Uygulanması, Milli Eğitim (179): 283-392.

Özdemir, S. (2001). Eğitimde Toplam Kalite Yönetimi, Manas Üniveritesi Sosyal Bilimler Dergisi, 1(2): 253-270.

Özer, M., Gür, B., ve Küçükcan, T. (2010). Yükseköğretimde Kalite Güvencesi. Ankara: Seta Yayınları.

Palıulıs, N. K., ve Labanauskıs, R. (2015). Benchmarking As An Instrument For Improvement Of Quality Management In Higher Education, Business, Management and Education, 140-157.

Parlar, H. (2012). Bilgi Toplumu, Değişim ve Yeni Eğitim Paradigması. Yalova Sosyal Bilimler Dergisi, (4):193-209.

Sönmez, V., ve Alacapınar, F. (2011). Bilimsel Araştırma Yöntemleri. Ankara: Anı.

Sözer, A. N., Tütüncü, Ö., Doğan, Ö. İ., Gencel, U., Gül, H., Tenikler, G., ve Devebakan, N. (2002). Dokuz Eylül Üniversitesi Sosyal Bilimler Enstitüsü'nde Lisansüstü Eğitim Kalitesinin Artırılmasına Yönelik Bir Alan Araştırması. Dokuz Eylül Üniversitesi Sosyal Bilimler Enstitüs Dergisi, 4(2): 41-65.

Şimşek, G. G. (2009). Türkiye'de Cep Telefonu Cihazı Pazarında Marka Sadakati İçin Bir Model Denemesi. Odtü Gelişme Dergisi, 36: 121-159. 
Taşkın, E., ve Büyük, K. (2002). Hizmet Pazarlaması Açısından Eğitim Hizmetlerinde Kalite (Kütahya'daki Özel Dershane Öğrencileri İle İlgili Bir Saha Araştırması). Sosyal Bilimler Enstitüsü (7): 223-224.

Tonta, Y. (1999). Bilgi Toplumu ve Bilgi Teknolojisi, Türk Kütüphaneciliği, 13(4): 363-375.

Veznedaroğlu, L. (2007). Okulda ve sınıfta örtük program: bir özel ilköğretim okulu örneği. (Yayınlanmamış Doktora Tezi) Ankara Üniversitesi Ĕ̆itim Bilimleri Enstitüsü, Ankara.

YÖK. (1983). Yükseköğretim Kurumları Teşkilatı Kanunu.Mart 28

YÖK. (2005). Türk Yükseköğretiminin Bugünkü Durumu. Ankara: Ankara Üniversitesi $\begin{array}{lllll}\text { Basımevi. } & 30 & \text { Ekim } & 2015 & \text { tarihinde }\end{array}$ http://www.yok.gov.tr/documents/10279/30217/turk_yuksekogretimin_bugunku_duru mu_kasim_2005.pdf adresinden erişildi.

Yüksel, S. (2002). Yükseköğretimde Eğitim-Öğretim Faaliyetleri ve Örtük Program, Uludă̆ Üniversitesi Ĕ̆itim Fakültesi Dergisi, 15(1): 361-370.

Zeithaml, V. (1998). Consumer Perceptions of Price, Quality and Value: A Means- End Model and Synthesis of Evidence, Journal of Marketing, 52: 2-22. 